\title{
Kampung 3G (Glintung Go Green): Ide Lokal Sebagai Solusi Global?
}

\author{
Ervina Fredayani ${ }^{1}$ \\ ervinafredayani7@gmail.com
}

\begin{abstract}
Abstrak
Penulisan ini bertujuan untuk meneliti Kampung 3G (Glintung Go Green) sebagai solusi dalam mencapai tujuan yang terdapat pada program SDG's (Sustainable Development Goals) yang dibuat oleh PBB (Perserikatan Bangsa-Bangsa). Penulis membahas isu terkait dengan lingkungan yang menjadi dasar terciptanya sebuah permasalahan-permasalahan lain yang sangat kompleks seperti kesehatan, kebersihan, ekonomi, dan sosial. Penelitian ini dilakukan penulis dengan menggunakan metode deskriptif kualitatif dengan teknik wawancara, studi dokumentasi dengan Ketua RW 23 Glintung Bapak Bambang Irianto, dan studi literatur, serta konsep pemberdayaan masyarakat sebagai cara pandang dalam melihat sebuah fenomena yang kami amati. Penulis ingin mengetahui bagaimana solusi yang ditawarkan oleh Kampung Glintung dalam mengatasi permasalahan lingkungan pada konteks SDGs. Selain itu penulis ingin mengetahui respon publik domestik maupun internasional terhadap ide Kampung $3 \mathrm{G}$ yang digunakan sebagai solusi untuk mewujudkan program SDGs.
\end{abstract}

Kata Kunci: Kampung 3G, Isu-isu Internasional dan Domestik, Sustainable Development Goals

\begin{abstract}
This paper aims to examine the Village 3G (Glintung Go Green) as a solution in achieving the goals contained in the program SDG (Sustainable Development Goals) made by the United Nations (United Nations). The author discusses environmental issues that form the basis of the creation of very complex issues such as health, hygiene, economics, and society. This research was conducted by the writer using a qualitative descriptive method with interview technique, documentation study with RW 23 Chair Glintung Bambang Irianto, and literature study, and the concept of community empowerment as a way of looking at the phenomena we observed. The author wants to know how the solution offered by Glintung Village in addressing environmental issues in the context of SDGs. In addition, the authors want to know the response of domestic and international communities to the idea of Kampung $3 \mathrm{G}$ which is used as a solution to realize the SDG program.
\end{abstract}

Keywords: International and Domestic Issues, Sustainable Development Goals, $3 G$ Village

\section{Pendahuluan}

Isu-isu global seperti isu lingkungan, perubahan iklim, kemiskinan, kesehatan, pendidikan, ketidaksetaraan gender menjadi permasalahan bagi seluruh negara-negara dunia yang telah terangkum dalam program SDGs. SDGs dibentuk melalui sidang PBB ke 70 pada September 2015 di New York, Amerika Serikat sebagai sebuah solusi lanjutan dari pembangunan global (Fitri, 2016). Program yang

\footnotetext{
${ }^{1}$ Korepondensi: Mahasiswi Program Studi Ilmu Hubungan Internasional, Fakultas Ilmu Sosial dan Ilmu Politik, Universitas Muhammadiyah Malang, Jl. Raya Tlogomas no. 246 Malang, telp. 0341 464318
} 
menjadi tujuan utama dari SDGs lebih bersifat universal dan memberikan ruang bagi seluruh negara untuk berkontribusi dan berperan penuh dalam pencapaian pembangunan tersebut. Didalam SDGs terdapat program yang disebut dengan $M y$ world survey, yaitu global survey bertujuan untuk menampung pandangan dan aspirasi masyarakat untuk menentukan agenda baru yang dianggap tepat untuk menciptakan dunia yang lebih baik. Hasil survey ini yang kemudian dijadikan salah satu pertimbangan untuk menentukan ke-17 tujuan yang ada di SDGs (Fitri, 2016).

Segala bentuk permasalahan akan selalu muncul dan menjadi bagian yang selalu dirasakan oleh seluruh negara-negara yang ada di dunia. Setiap permasalahan selalu berusaha diselesaikan oleh negara dengan cara menciptakan sebuah solusi yang tepat untuk mencegah adanya perluasan permasalahan pada aspek-aspek yang lain. Seperti yang terjadi saat ini telah banyak isu-isu global yang berdampak pada domestik suatu negara, seperti isu banjir yang berdampak pada lingkungan, kemiskinan, kesehatan, lingkungan, dan masih banyak lagi. Permasalahanpermasalahan tersebut telah menjadi masalah yang mengglobal bagi negara-negara di seluruh dunia baik itu negara maju maupun berkembang. Hal tersebut disebabkan oleh adanya globalisasi yang memberikan efek begitu besar bagi dunia, mulai dari perluasan isu-isu domestik, persebaran informasi hingga hubungan antar negara yang tiada batasnya.

Disini penulis membahas masalah terkait dengan isu lingkungan dimana hal ini dianggap memiliki dampak yang cukup besar dalam kehidupan kita sehari-hari. Permasalahan ini menjadi menarik karena tanpa kita sadari bahwa lingkungan sangat berpengaruh dalam setiap aspek kehidupan seluruh umat manusia dan tentunya telah membawa banyak dampak yang cukup signifikan pada kehidupan kita, selain itu isu ini telah menjadi isu global yang sampai saat ini masih belum bisa terselesaikan (Irianto, 2018). Meskipun telah banyak solusi yang dihadirkan dan diberikan untuk mengatasi isu tersebut. Adapun solusi yang biasa dilakukan yaitu dengan membentuk masyarakat sadar lingkungan, pembentukan institusi dalam penyediaan informasi terhadap lingkungan, sosialisasi akan pentingnya lingkungan, dan penetapan kebijakan dari pemerintah (Suranto, 2007). Akan tetapi dari solusi-solusi itu masih belum bisa digunakan untuk mengatasi isu tersebut. Dalam mengatasi suatu isu yang 
telah mengglobal, penting adanya peran dan kesadaran dari masing-masing individu untuk bisa menjaga lingkungan.

Kesadaran dan kemauan ini dimulai dari lingkungan sekitar, dimana hal ini menjadi yang paling mudah untuk dilakukan dan sebagai bentuk dari upaya dalam mengembalikan tatanan lingkungan agar dampak dari permasalahan banjir yang tentunya sangat meresahkan serta berdampak pada faktor-faktor kehidupan lainnya. Salah satu inspirasi baru sebagai solusi untuk memperbaiki lingkungan atau solusi untuk permasalahan banjir tersebut lahir dari kampung Glintung, yaitu salah satu kampung yang terletak di Kota Malang, Jawa Timur. Kampung Glintung menjadi lokasi yang menarik untuk diteliti sebab peranannya yang besar terhadap perubahan tatanan kampung-kampung dan berupaya menghijaukan kembali Kota Malang (Irianto, 2018). Hal ini dibuktikan dengan adanya prestasi yang sempat diraih oleh kampung 3G ini dalam ajang Guangzhou Award For Urban Innovation sebagai 15 Top dari 301 kota di dunia (Publik, 2017).

Selain itu juga keberhasilannya dalam menjadi inovasi bagi kampungkampung kumuh yang ada di Malang, sehingga mulai muncul kampung tematik dan kampung-kampung lain di Kota Malang untuk menangani permasalahan yang sama dengan di Kampung Glintung. Ide ini juga sudah mulai diterapkan di kota-kota besar seperti di Tangerang, Banten, dan Sumatera (Irianto, 2018). Perubahan ini menjadi salah satu solusi baru untuk menciptakan penghijauaan kembali di wilayah padat penduduk yang tentunya tidak memiliki lahan yang cukup untuk membangun taman atau hutan, akan tetapi Kampung Glintung mampu menciptakan sebuah ide dengan memanfaatkan dinding atau bangunan sebagai lokasi penghijauan di daerah yang padat penduduk.

Kampung Glintung merupakan sebuah kampung yang dahulunya sama dengan kampung-kampung sebagian besar di Kota Malang, yaitu kampung yang cenderung kumuh, dengan tingkat pengangguran serta kriminalitas yang cukup tinggi dan juga salah satu kampung yang kerap kali terendam banjir saat musim penghujan datang (Irianto, 2018). Tidak sedikit masyarakat di Kampung Glintung pada saat itu memiliki pemikiran yang kolot dan tertutup, serta acuh terhadap lingkungan. Akan tetapi, setelah adanya ketua RW di wilayah tersebut yaitu Bapak Bambang Irianto yang memiliki pemikiran luas dan kepedulian terhadap lingkungan bisa mengubah 
kampung yang kumuh tersebut menjadi hijau dengan memanfaatkan apapun yang ada di sekitarnya dan menrapkan konsep Glintung Go Green (melalui web kampung 3G, 2018).

Perubahan pola pikir dan kebiasaan masyarakatnya berusaha dibangun dan diubah sedikit demi sedikit agar sadar akan lingkungan sekitarnya. Hal itu menjadi tantangan tersendiri dalam kepemimpinannya untuk mengubah kampung dengan mencoba menerapkan aturan bahwa setiap warga kampung Glintung yang berurusan dengan RW maka diwajibkan untuk membawa tanaman, hal ini dilakukan untuk memaksa warganya sadar dan peduli akan pentingnya penghijauan bagi kehidupan kita. Dari hal tersebut kemudian masyarakat diajak untuk melakukan perubahan dengan menanam pohon-pohon dan menatanya dengan memanfaatkan dinding-dinding bangunan di sepanjang Kampung Glintung. Penerapan Glintung Go Green yang awalnya hanya untuk menciptakan tatanan lingkungan yang bersih juga berdampak pada aspek-aspek lainnya seperti halnya pengurangan angka pengangguran di kampung tersebut dan berkurangnya kasus kriminalitas.

Penciptaan Kampung 3G ini dirintis dengan cara-cara yang sangat sederhana, tanpa mengeluarkan uang sedikitpun. Ketua RW kampung tersebut memiliki inisiatif bahwa semua tanaman-tanaman yang akan dimanfaatkan untuk penghijauan ini diambil dari tanaman yang terdapat di sepanjang pinggir sungai, selain itu masyarakatnya juga berusaha memanfaatkan barang-barang bekas seperti panci, timba air sebagai pot untuk tanamannya (Irianto, 2018). Kesederhanaan dan adanya kemauan masyarakat untuk merintis kampung yang asri dan sejuk ini berbuah manis, yang sekarang ini Kampung 3G terkenal hingga di dunia internasional. Sehingga disini penulis ingin mengetahui bagaimana solusi yang ditawarkan oleh Kampung Glintung dalam mengatasi permasalahan lingkungan dalam konteks SDGs dan respon publik, domestik, maupun internasional terhadap hal tersebut.

Tujuan dari penelitian ini adalah untuk mengetahui pengaruh isu internasional terhadap ide-ide lokal, mengetahui peranan dari Kampung Glintung dalam SDGs, serta pentingnya Kampung Glintung sebagai inisiator dalam mengatasi isu global yang terdapat dalam program SDGs. Adapapun penelitian ini bermanfaat dalam mengetahui pengaruh isu internasional yang diberikan terhadap munculnya ide-ide lokal, mengetahui peranan dari Kampung Glintung dalam mengatasi isu-isu 
global, dan sebagai solusi serta inisiator untuk wilayah lain dalam mengatasi isu-isu global yang ada saat ini.

\section{Tinjauan Pustaka}

Pada pembuatan sebuah penelitian kita tentunya perlu mengacu pada penelitian terdahulu sebagai sebuah pembeda dari peneliti yang akan kita lakukan. Penelitian pertama dari Ima Hidayati Utami yang berjudul "Strategi Penguatan Kampung Glintung Go Green (3G) sebagai Destination Branding Obyek Wisata Edukasi di Malang” (Utami, 2017), yang mana dalam penelitiannya ini menjelaskan bagaimana kampung Glintung bisa menjadi sebuah objek wisata edukasi di kota Malang. Menurut web resmi dari Kampung Glintung Go Green (3G), kampung ini berhasil masuk dalam 5 besar sebagai kampung hijau di Kota Malang, selain itu di kampung ini juga berhasil menciptakan sebuah inovasi-inovasi untuk mengelola kampung di lingkungan perkotaan dan mulai dijadikan sebagai rujukan oleh daerahdaerah lain di seluruh Indonesia. Wisatawan dari berbagai negara juga datang untuk melihat dan mempelajari Kampung Glintung sebagai sebuah inovasi baru dari sebuah kampung di lingkungan perkotaan, dan tentunya potensi itu dapat dijadikan sebuah peluang untuk menciptakan destinasi wisata edukasi.

Hasil yang di dapatkan dari penelitian tersebut ialah, adanya sebuah potensi yang dapat dikembangkan oleh Kampung Glintung Go Green (3G) untuk membangun sebuah wisata edukasi di wilayah Kota Malang. Namun tahapan-tahapan dalam menciptakan Kampung Glintung sebagai Destination Branding harus dilakukan, untuk menguatkan citra kampung Glintung sebagai sebuah kampung wisata. Penelitian ini berhasil mengembangkan faktor-faktor yang menjadi dasar untuk menciptakan Kampung Glintung Go Green (3G) sesuai dengan konsep branding dan juga memperbaiki kembali visi, misi, brand essence, dan juga brand image Kampung Glintung. Usaha tersebut digunakan untuk menguatkan destination branding Kampung Glintung sebagai kampung wisata edukasi berbasis lingkungan, peneliti juga melakukan kerjasama dengan manajemen 3G, tokoh masyarakat, dan perwakilan warga menetapkan langkah-langkah yang pasti dalam mewujudkan Kampung Glintung sebagai destinasi wisata. 
Penelitian kedua, Tri Yulianti dengan judul "Penguatan Institusi Lokal dan Menggerakkan Modal Sosial Melalui Komunitas untuk Menciptakan Kampung Berdaya" (Yulianti, 2018). Penelitian ini bertujuan untuk melihat bagaimana perkembangan Kampung 3G (Glintung Go Green) yang dulunya kumuh, memiliki banyak permasalahan serius di dalam kampungnya, dan juga memiliki tingkat ekonomi warganya rendah, sekarang mampu menjadi kampung yang berdaya secara sosial, ekonomi dan budaya. Hal tersebut terjadi karena usaha yang dilakukan oleh warganya atas dasar kepedulian terhadap lingkungan. Konsep Kampung $3 \mathrm{G}$ dianggap Kementrian Dalam Negeri (Kemendagri) sangat inovatif dan layak jadi percontohan Nasional. Kemampuan ketua RW dalam mengkoorinir warga masyarakatnya untuk bisa bersama-sama wewujudkan kampung impian, dan juga untuk mengatasi maslaahmasalah yang ada di kampung tersebut. Tujuan dari penelitian yang dilakukan ini adalah untuk mengkaji bagaimana seorang Ketua RW yang menjadi Agen dalam melayani warganya mampu memperkuat intitusi lokal dan menggerakkan modal sosial, serta upaya warga Kampung 3G menciptakan kampung yang berdaya.

Hasil dari penelitian yang dilakukan ini adalah bagaimana usaha yang dilakukan oleh ketua RW di Kampung Glintung telah berhasil memberdayakan masyarakatnya untuk menciptakan kampung yang tertata rapi dan berhasil menyelesaikan masalah-masalah yang ada di dalam kampung tersebut. Keberhasilan RW 23 Kelurahan Purwantoro Kabupaten Malang merupakan wujud dari keberhasilan pembangunan yang menuntut partisipasi warga dan komitmen pimpinan. Kemandirian adalah kunci utama yang di dapatkan dalam mewujudkan kampung tersebut, usaha keras dari ketua RW yang tidak hanya menjalankan fungsinya sebagai seorang pemimpin yang hanya melayani keperluan administrasi kependudukan semata, akan tetapi juga harus menjadi manajer wilayah yang harus membangun bersama masyarakat. Tentunya setiap kegiatan dan usaha-usaha yang dilakukan oleh Kampung Glintung berdasarkan pada kesepakatan hasil rapat, dan tidak hanya diputuskan oleh ketua RW tetapi berdasarkan pada pendapat serta hasil dari musyawarah yang dilakukan.

Penelitian ketiga, M. Nuh, Erlita Cahyasari, Niken Lastiti, dan Suhartono Winoto dalam judulnya "Gender Adjustment for Sustainable City (Case of $3 G$ (Glintung Go Green) in Malang City)" (Nuh, Cahyasari, Anggaini, \& Winoto, 2018). Penelitian ini 
meneliti tentang isu gender sebagai salah satu faktor dari keberhasilan terwujudkan kampung Glintung. Adanya faktor jenis kelamin dalam sebuah kelompok tentunya memiliki pengaruh yang besar dalam lingkungan kota. Tujuan dari penelitian ini adalah untuk memberikan keterwakilan hubungan antara gender dan program kota yang berkelanjutan, terutama dalam mensukseskan kegiatan di Kampung 3G (Glintung Go Green). Dimana peran Gender yang tidak hanya merujuk pada perbedaan anatara perbedaan antara perempuan dan laki-laki, tetapi juga pada tingkat perbedaan di mana gender beroperasi atau bekerja, perbedaan tersebut menciptakan norma-norma sosial dan budaya, harapan, pola perilaku dan ideologi tersendiri. Tentunya keberadaan partisipasi gender dalam membangun suatu tatanan wilayah dan dalam perencanaan program pembangunan berpengaruh dalam perwujudannya.

Hasil penelitian yang dilakukan, menunjukkan bahwa partisipasi dari masyarakat dalam membangun dan juga mensukseskan program Kampung 3G tidak dilakukan oleh seluruhnya, tetapi hanya sebagian besar masyakarat yang terlibat. Keberhasilan yang didapatkan dalam mewujudkan Kampung $3 G$ saat ini bukan berdasarkan pada faktor gender, bahkan jika keterlibatan dan partisipasi gender benar-benar aktif dan dapat dianggap sebagai keberhasilan, tetapi tetap tidak memiliki efek apa pun pada gender. Persepsi gender menunjukkan bahwa tidak semua keberhasilan program dapat mengangkat peran dan keterlibatan gender. Dalam hal ini jenis kelamin bukanlah satu-satunya kelompok sosial yang mampu mempengaruhi tetapi keberadaan gender sangat penting dalam menjaga dan melestarikan keberlanjutan program Kampung 3G. Keterbukaan manajemen keuangan memiliki pengaruh yang kuat dalam membangun citra dan kepercayaan dari masyarakat. Keterbukaan akan membangun kepercayaan dan meminimalkan resistensi yang terbentuk di masyarakat. Selain itu, keterbukaan yang juga perlu diperkuat adalah peran dan keterlibatan. Semua masyarakat perlu diberi kesempatan untuk terlibat dan berpartisipasi aktif dalam mengelola program Kampung 3G.

\section{Metode}

Pada penelitian ini penulis menggunakan metode penelitian deskriptif dengan pendekatan kualitatif. Selain menggunakan metode tersebut penulis juga menggunakan teknik wawancara dan studi dokumentasi dengan Ketua RW 23 
Kampung Glintung Bapak Bambang Irianto, dan studi literatur baik online maupun cetak. Metode penelitian deskriptif kualitatif merupakan metode penelitian multi fokus, yang melibatkan penafsiran, pendekatan naturalistik dengan materi pelajaran yang ada (Emzir, 2011). Metode penelitian kualitatif bertujuan untuk menggambarkan suatu fenomena tertentu, baik yang bersifat alamiah maupun rekayasa atau untuk menentukan ada tidaknya keterkaitan di antara suatu gejala dengan gejala lainnya yang relevan dengan penelitian. Selain itu, tulisan ini bersifat deskriptif analitik, yaitu dengan menganalisis fakta-fakta yang terjadi menggunakan teori dan konsep yang memiliki keterkaitan dengan fenomena tersebut. Kemudian, hasil analisis data dipaparkan dalam bentuk uraian.

Sedangkan teknik wawancara merupakan salah satu cara bagaimana penulis mengumpulkan berbagai data untuk memperkuat dan menekan kesalahankesalahan akan data yang didapat dalam memaparkan sebuah artikel ilmiah (Drg. K.R. Soegijono, 1993). Tujuan dari adanya teknik wawancara ini yaitu untuk memberikan kemudahan pada penulis dalam mendapatkan informasi terkait hal-hal yang dibutuhkan. Selain teknik wawancara penulis juga menggunakan studi literatur dan studi dokumentasi baik online maupun cetak untuk menambah dan mengumpulkan data-data untuk penelitian kami.

Selain metode dan teknik dalam pengumpulan data yang penulis tekankan, penggunaan konsep dalam menganalisa hasil penelitian juga penting untuk penulis gunakan yaitu konsep pemberdayaan. Konsep pemberdayaan merupakan proses untuk membuat masyarakat berdaya, dalam artian masyarakat memiliki kekuatan dalam mengelola potensi-potensi yang ada di sekitarnya, serta kemampuan dalam menciptakan kemandirian dalam diri mereka (Nugroho, 2008). Konsep pemberdayaan masyarakat ini tidak lain adalah usaha dalam meningkatkan kemampuan masyarakat dalam membawa dirinya kearah yang lebih baik. Selain itu konsep pemberdayaan masyarakat ini juga berusaha untuk menciptakan kesadaran, pemahaman, pemanfaatan, dan pembiasaan (Wulan, 2013) agar tujuan dari sebuah program bisa tercapai dan keinginan dalam memberdayakan masyarakat bisa terwujud.

Pada konsep pemberdayaan dijelaskan bahwa terdapat beberapa indikator bahwa suatu pemberdayaan itu bisa dikatakan berhasil. Seperti halnya 
indikator kemampuan masyarakat dalam mengelola potensi yang ada disekitarnya menjadi meningkat, kesadaran masyarakat akan pemahaman pentingnya suatu tujuan yang ingin mereka capai, dan pembiasaan diri dari masyarakat untuk berbuat sesuatu hal yang lebih baik dari sebelumnya (Wulan, 2013). Beberapa indikator tersebut menjadi hal mendasar dari keberhasilan pemberdayaan yang dilakukan oleh seorang pelopor atau pemimpin dalam mencapai tujuan untuk menyelesaikan permasalahan terkait dengan ketidakberdayaan masyarakatnya.

Dalam menganalisa Kampung 3G sebagai solusi dalam program SDG's penulis menggunakan konsep pemberdayaan masyarakat, sebab konsep ini dianggap cocok untuk melihat hasil ide dari tercetusnya Kampung 3G (Glintung Go Green) yang mana kampung tersebut bisa menjadi inisiator bagi negara-negara lain hingga di kancah Internasional. Sehingga hal ini nantinya akan digunakan untuk melihat seberapa besar dampak pemberdayaan Kampung 3G terhadap masyarakat disekitarnya dan wilayah-wilayah lain dalam membantu memberdayakan masyarakatnya.

\section{Hasil dan Pembahasan}

Glintung Go Green merupakan sebuah solusi yang hadir dari pemikiran Bambang Irianto yang awalnya hanya ingin merubah kampungnya yang dulu kumuh menjadi bersih dan hijau (melalui web kampung 3G, 2018). Hal ini menjadi salah satu bentuk transfer ide yang dilakukan oleh kampung Glintung dalam menghadapi masalah-masalah global yang ada didalam SDGs tersebut, ini menunjukkan bahwa penerapan kampung Glintung Go Green tersebut merupakan langkah awal bagi Indonesia untuk mampu mewujudkan program-program dalam SDGs. Pada awalnya Kampung 3G ini merupakan kampung yang amat kumuh dengan angka kemiskinan dan kriminalitas yang tinggi, rendahnya tingkat kesehatan dan kesadaran akan pentingnya lingkungan (melalui web kampung 3G, 2018). Kondisi kampung yang seperti itu dan melihat isu-isu yang semakin mengglobal membuat ketua RW 23 memiliki ide untuk mengatasi permasalahan tersebut.

Sejak dimulainya program penghijauan Kampung Glintung pada 2013 hingga saat ini telah memberikan banyak partisipasi dari berbagai pihak mulai dari pemerintahan hingga non-pemerintahan (Irianto, 2018). Apresiasi yang tinggi 
diberikan oleh Pemerintah Malang kepada Kampung Glintung dan juga pencetusnya yaitu Bapak Bambang Irianto atas berbagai penghargaan yang telah dicapai terkait $3 \mathrm{G}$ (Malang, 2017). Ketertarikan pemerintah dalam pengelolaan Kampung Glintung untuk saat ini hanya sebatas penyuluhan dan bantuan dalam hal pendanaan demi berlangsungnya 3G. Hingga saat ini, menurut penyampaian Pak Bambang selaku ketua RW menyampaikan bahwa pemerintah baik Kota Malang maupun Nasional belum pernah sekalipun menerapkan suatu kebijakan untuk wilayah-wilayah lain dalam menerapkan inovasi baru dari gerakan 3G.

Meskipun tidak dalam penerapan kebijakan pemerintah, Kampung Glintung menjadi suatu ide atau isu dan jejaring dalam kajian Isu-isu Internasional dan Domestik (Irianto, 2018). Lingkupnya adalah suatu ide lokal yang menjadi ide global. Dimulai dari lingkup kampung lain hingga internasional, Kampung Glintung mampu menjadi inspirasi dalam pengelolaan desa dan wilayah lain. Desa Gedangan (Sidoarjo) yang termotivasi untuk mengikuti konsep 3G (Nations, 1992) dan Desa Grendeng Pulo (Tangerang) yang menjadi desa binaan 3G oleh Kampung Glintung menjadi contoh bahwa ide ini mampu berperan dalam ruang lingkup nasional serta terpilihnya kampung ini sebagai inovasi pertama di dunia dalam ajang Ghuangzou Award Urban Innovation 2016 yang disponsori oleh United Cities and Local Government (UCLG), Asosiasi Dunia Metropolises Utama (Metropolis), dan Kota Guangzhou menjadi bukti bahwa ide lokal 3G ini mampu memberikan konsep dan inovasi secara internasional, didukung dengan fakta bahwa Kampung Glintung adalah kampung konservasi air pertama di dunia, yang diresmikan oleh Menteri Dalam Negeri Indonesia Tjahjo Kumolo pada 19 Juli 2017 (Irianto, 2018).

Glintung Go Green saat ini telah menerapkan sebagian besar poin dari 17 poin Sustainable Development Goals yang memang pada dasarnya menjadi alasan warga Kampung Glintung menerapkan Go Green. 11 dari 17 aspek pembangunan berkelanjutan yaitu poin nomor 1, 3, 4, 6, 7, 8, 9, 11, 13, 15, dan 17 mampu diterapkan di $3 \mathrm{G}$ selain pada faktor lingkungan, faktor kesejahteraan dan masyarakat juga terlibat dalam SDG's. Dampak terbesar dari penghijauan kampung mampu mengubah kehidupan masyarakat dimana kesehatan warga lokal membaik dilihat dari tingkat kematian yang cukup rendah dibanding sebelum 3G ini diterapkan, tingkat kriminalitas menurun dikarenakan masyarakat memiliki pekerjaan dan penghasilan 
dari konservasi kampung, banjir tidak pernah terjadi lagi semenjak sanitasi air yang diperbaharui sehingga daya resap air hujan dapat efektif, dan masyarakat sekitar pada akhirnya memiliki kualitas udara yang lebih baik (Irianto, 2018).

Dari pembentukan kampung 3G (Glintung Go Green) banyak sekali dampak positif yang diberikan terhadap masyarakat di lingkungan tersebut. Sebelum adanya pembentukan kampung 3G, daerah Glintung yang dulunya terkenal dengan wilayah yang kumuh sekarang menjadi wilayah yang sangat asri dan sejuk (Irianto, 2018). Tidak sedikit permasalahan-permasalahan yang muncul sebelum kampung $3 \mathrm{G}$ ini tercipta, seperti tingginya tingkat kemiskinan, rendahnya pelayanan kesehatan, tingginya angka kematian, angka kriminalitas yang tinggi serta kekumuhan setiap lorong wilayah tersebut. Permasalahan-permasalahan tersebut merupakan hal-hal yang memang dialami oleh banyak daerah selain Glintung, akan tetapi adanya kesadaran dari Ketua RW Glintung yaitu Bapak Bambang Irianto terhadap pentingnya lingkungan dan kesehatan menjadikan kampung yang kumuh menjadi daerah yang saat ini terkenal dengan keasrian dan kesejukannya.

Melihat dari kemampuan-kemampuan yang dicapai oleh warga Glintung ini menimbulkan perubahan yang sangat signifikan dalam kondisi masyarakat di Glintung. Masyarakat di Glintung yang pada awalnya memiliki angka kematian yang tinggi serta kesehatan yang rendah, semenjak terciptanya Kampung 3G ini angka kematian menurun dengan sangat signifikan (Irianto, 2018). Hal ini disebabkan karena adanya kesadaran masyarakat dalam menjaga kebersihan dan menjaga pola makan yang sehat dari hasil tanaman yang mereka tanam di sepanjang kampung Glintung. Menurunnya angka kriminalitas di Glintung juga menjadi dampak positif dari terciptanya Kampung 3G, sebab selain menciptakan wilayah yang asri dan sejuk kampung 3G ini berhasil membuka lapangan pekerjaan baru bagi masyarakatnya dengan cara mengadakan edukasi wisata di kampung tersebut. Banyak para pengunjung yang ingin belajar cara-cara menanam dan merawat tanaman hingga bisa memberikan manfaat yang cukup besar bagi kita. Pembuatan saluran air, alat penanaman biopori juga menjadi pekerjaan baru bagi masyarakat, karena hal tersebut menjadikan pengunjung dari daerah-daerah lain memesannya untuk digunakan di rumah mereka (Irianto, 2018). Sehingga dari adanya itu, masyarakat menjadi memiliki peluang baru dalam meningkatkan perekonomian mereka. 
Keberhasilan Kampung 3G dalam menciptakan suatu pemberdayaan tidak hanya terwujud pada lingkungan lokal di daerah Glintung, akan tetapi hal ini juga terjadi di daerah lain seperti di Kota Tangerang, Kalimantan, Sumatera, dan lain sebagainya (Irianto, 2018). Pemberdayaan yang terjadi hingga ke berbagai provinsi ini terjadi karena adanya pentransferan ide melalui berbagai proses dan jejaring yang ada, baik itu individu, kelompok, maupun organisasi. Keberhasilan Kampung 3G ini tidak berhenti hanya pada sampai kemiskinan, kriminalitas, kesehatan akan tetapi berlanjut hingga sampai beberapa tujuan yang ada dalam program SDG's, yaitu terkait dengan pemberdayaan masyarakat dalam tujuan kesetaraan gender, permasalahan perubahan iklim, air bersih dan sanitasi air dalam program kampung 3G GEMAR (Gerakan Menabung Air), kelaparan, energi yang yang terjangkau dan bersih (Irianto, 2018). Hal-hal tersebut dapat dikatakan bahwasannya Kampung 3G ini mampu dalam memberdayakan masyarakatnya walau hanya dengan pembentukan satu ide Glintung Go Green, akan tetapi banyak menfaat yang dapat diperoleh masyarakat sekitarnya.

Melihat keberhasilan Kampung $3 G$ dalam mengatasi berbagai permasalahan yang ada dalam program SDG's ini, menjadikan Glintung sebagai inisiator dalam solusi SDG's. Solusi yang diberikan Glintung ini menjadi sebuah terobosan baru bagi negara-negara di dunia ini untuk menerapkan program seperti yang diciptakan oleh Bapak Bambang Irianto dalam mengatasi permasalahan yang ada di Glintung. Penerapan solusi ini dalam SDG's akan bisa membantu negaranegara yang memiliki permasalahan sama untuk ditanganinya. Apabila solusi dari Glintung ini bisa menjadi sebuah acuan dalam mengatasi permasalahan dalam 17 tujuan yang ada dalam SDG's maka akan bisa memberikan manfaat dan pengaruh yang besar bagi kemajuan setiap wilayah baik itu lokal, nasional, hingga internasional.

\section{Kesimpulan}

Seperti yang diuraikan diatas, bahwa isu-isu yang paling berkembang di dunia telah dirangkum dalam SDGs, dan hal ini merupakan salah satu bentuk dari PBB sebagai organisasi dunia untuk bisa mengatasi masalah-masalah tersebut bersama dengan seluruh lapisan masyarakat. Peran masyarakat sangat dibutuhkan dalam mengatasi masalah tersebut, karena permasalahan tersebut hadir dan berkembang dalam masyarakat. Permasalahan ini akan bisa diselesaikan dengan cara 
meningkatkan kesadaran serta bantuan pemerintah setempat. Seperti halnya isu lingkungan yang sedang menjadi masalah penting, karena tidak hanya negara-negara tertentu yang merasakan dampaknya tetapi hampir di seluruh dunia mengalami masalah terhadap perubahan lingkungan. Hal tersebut menjadi dasar mengapa negara-negara berupaya untuk mengatasi masalah ini. Mengapa isu ini juga memiliki dampak tidak hanya pada satu aspek saja tetapi juga hal ini akan menjadi efek domino, peristiwa ini berhubungan dengan kemiskinan, pertumbuhan ekonomi serta terjadinya ledakan jumlah penduduk.

Sebagai kampung yang pada awalnya memiliki tingkat kriminalitas dan kematian yang tinggi, tingkat kesehatan yang rendah, potensi banjir sangat tinggi, kesadaran masyarakat akan lingkungan begitu rendah, dan partisipasi masyarakat dalam bermasyarakat begitu rendah, Kampung Glintung memulai mengubah diri menjadi Kampung Go Green diprakarsai oleh Ketua RW Bambang Irianto dengan melakukan penyuluhan dan berupaya untuk merubah mindset masyarakat agar sadar lingkungan dan ingin bergerak hati dan tindakannya untuk bersama-sama memajukan 3G tersebut. Menurut Ketua RW, tahun pertama adalah tahun yang sangat berat untuk mengubah kebiasaan masyarakat yang acuh terhadap sekitar menjadi sedikit lebih terbuka untuk memajukan kampung. Permasalahan utama adalah pada begitu rendahnya perekonomian masyarakat dan sedikitnya uang kas yang dimiliki RW tersebut menjadi kendala terbesar untuk terus berkembang. Motivasi, contoh yang konkrit dan mudah ditiru, dari berbagai barang yang ada dari sampah dan tidak harus uang, dan jiwa gotong royong adalah semangat yang dimiliki oleh ketua RW. "Bangunlah Jiwanya Bangunlah Badanya". Sepenggal lirik Lagu Indonesai Raya tersebut menjadi pedoman Pak Bambang dalam membangun kampung dan masyarakat Kampung Glintung (Irianto, 2018).

Banyak manfaat yang didapatkan dari pembentukan kampung 3G ini, misalnya manfaat yang telah dirasakan masyarakat yaitu mulai hilangnya permasalahan-permasalahan seperti kemiskinan, kriminalitas, dan lingkungan yang kumuh. Hal ini disebabkan adanya keberhasilan dari penggagas ide kampung 3G dalam menciptakan pemberdayaan masyarakatnya. Dalam hal ini dikatakan berhasil dalam memberdayakan masyarakatnya karena kemampuan dari setiap elemen-elemen dalam proses pemberdayaan masyarakat dalam melewati setiap tahapan-tahapan yang 
ada seperti kemampuan dalam menyadari akan pentingnya lingkungan yang bersih, pemahaman akan pentingya kehidupan yang layak dan sejahtera, kemampuan dalam memanfaatkan setiap potensi yang ada di sudut-sudut lorong, dan kemampuan menjadi individu yang mandiri dan membiasakan diri dalam menjaga lingkungan sekitarnya (Wulan, 2013).

Setelah 3 tahun 3G ini berjalan, perubahan terjadi begitu pesat baik dari sisi lingkungan dan masyarakatnya. Menurut Ketua RW Bambang Irianto, keberhasilan tertinggi dalam revolusi kampungnya adalah ketika masyarakat sudah mulai mengerti urgensi lingkungan dalam kehidupan sehingga warga lokal tergerak hati dan keinginannya dalam memajukan lingkungan kampung. Pada akhirnya, 3 tahun ini diikuti dengan meningkatnya kesehatan masyaratan dan kemiskinan yang berkurang sebagai aspek nomor 1 dalam SDG's mampu membawa Kampung Glintung ke level yang lebih tinggi. Tidak hanya menjadi dasar ide dan konsep dalam kampung lainnya di Indonesia, juga mampu memberikan inovasi kepada dunia melalui Award Urban Innovation 2016 dan ide lokal dari kampung ini mampu memberikan ide ke ruang lingkup yang lebih luas.

Menurut penulis, Kampung Glintung sebagai contoh konsep pemberdayaan Sumber Daya Manusia (SDM) yang menjadi aspek penting dalam melakukan pembangunan berkelanjutan memang perlu dilakukan dalam ruang lingkup yang lebih luas untuk mewujudkan SDG's yang ingin dicapai tersebut. Seperti yang telah dijelaskan pada result dimana untuk mewujudkan 3G tanpa biaya yang tinggi dan mengharapkan bantuan dari luar, Bambang Irianto lebih memfokuskan untuk mengubah mindset dan perilaku masyarakat secara perlahan dan dengan sedikit paksaan. Dengan tujuan awal untuk mewujudkan SDG's nomor 15 tentang Life on Land'. Dengan berhasilnya pembangunan berkelanjutan tersebut mampu membuat nilai-nilai SDG's lainnya mengikuti.

Aksi nyata yang telah dilakukan Kampung Glintung pada akhirnya mendapatkan pengakuan secara internasional pada Award Urban Innovation 2016 di Guangzhou. Lebih hebatnya lagi adalah, jika 9 inovasi hebat dari negara lainnya berasal dari suatu kota, perlu disadari bahwa Glintung ini hanyalah sebuah kampung kecil di Kota Malang. Pemberdayaan air, masyarakat, dan lingkungan mampu membuat Kampung Glintung disorot dunia (Wulan, 2013) dan semakin berjalannya 
waktu diharapkan Kampung Glintung ini menjadi sumber ide bagi tidak hanya Pemerintah Indonesia saja, tetapi menjadi ide yang mendunia dan mampu mempengaruhi suatu kebijakan lingkungan entah itu dari suatu pemerintahan, organisasi, ataupun think-tank global.

Penerapan solusi ini akan bisa memberikan terobosan baru bagi negaranegara berkembang maupun maju untuk memenuhi dan mencapai 17 tujuan SDG's dalam memerangi permasalahan-permasalahan yang saat ini semakin kompleks. Dengan usaha meningkatkan kesadaran masyarakatnya akan pentingnya sebuah penghijauan dan penampungan air, maka akan memberikan pemahaman dan manfaat yang besar bagi daerah mereka, seperti kemampuan masyarakat dalam memanfaatkan potensi di lingkungan sekitar mereka seperti penanaman sayur dengan biopori, hal tersebut bisa menghemat pengeluaran perekonomian mereka dan membuat hidup mereka lebih sehat sehingga bisa mengurangi angka kematian yang tinggi di negara mereka. Tidak hanya itu, manfaat yang bisa didapatkan dari penghijauan juga akan bisa dirasakan dengan adanya iklim yang sejuk di berbagai belahan dunia karena tidak banyak polusi yang meluap dan menyebabkan perubahan iklim yang begitu drastis. Masih banyak manfaat-manfaat dan pengaruh positif yang akan didapatkan oleh seluruh manusia di dunia ini jika mereka mapu menyadari, memahami, memanfaatkan, dan mebiasakan untuk hidup dalam kondisi lingkungan yang nyaman.

Menurut penulis, ide pembentukan Kampung 3G ini sangatlah efisien jika bisa diterapkan dalam mengatasi isu-isu yang ada saat ini dan sesuai dengan 17 tujuan yang ingin dicapai dalam program SDG's PBB. Sebab dari hasil penelitian kami, banyak sekali manfaat yang didapatkan oleh warga Glintung dalam menerapkan penghijauan dan sanitasi air untuk menjaga dan mewujudkan kesejahteraan di lingkungan mereka. Bukti keberhasilannya dalam memberdayakan masyarakatnya juga terlihat pada kemampuan mereka menembus Guangzhou Award for Urban Inovation pada tahun 2016 di Tiongkok (Irianto, 2018). Hal ini menjadi bukti nyata bahwa ide dari Glintung ini tepat untuk bisa dijadikan solusi dalam program SDG's dari Perserikatan Bangsa-Bangsa (PBB). Selain itu pembangunan kerjasama yang dijalin dengan berbagai perusahaan dan organisasi-organisasi menjadi suatu bentuk dari Glintung untuk mengajak masyarakat di berbagai wilayah menerapkan ide inovatifnya dalam membangun daerah yang lebih baik lagi. Serta, peranannya dalam mewujudkan 
SDG's menjadi alasan yang mendasar kenapa solusi dari Glintung ini patut untuk dijadikan solusi dalam mewujudkan program SDG's PBB.

\section{Daftar Pustaka}

\section{Buku}

Emzir. (2011). Metodologi Penelitian Kualitatif Analisis Data. Jakarta: Rajawali Pers.

\section{Jurnal}

Fitri, P. S. (2016). Perkembangan Pelaksanaan Sustainable Development Goals (SDGs) di Indonesia September 2015 - September 2016. https://www.sdg2030indonesia.org/an-component/media/uploadbook/Briefing_paper_No_1_SDGS_-2016-Meila_Sekar.pdf

Goals, S. D. (2018, April 20). Tujuan SDGs. Retrieved from Sustainable Development Goals: https://www.sdg2030indonesia.org/page/1-tujuan-sdg

Nations, U. (1992). United Nations Framework Convention. United Nations Framework Convention. https://unfccc.int/resource/docs/convkp/conveng.pdf

Nugroho, A. S. (2008). Paridigma, Model, Pendekatan Pembangunan dan Pemberdayaan Masyarakat di era Otonomi Daerah. Journal Unair Vol.2 No.1. http://journal.unair.ac.id/downloadfull/KMP81723fff561d1bfullabstract.pdf

Nuh, M., Cahyasari, E., Anggaini, N. L. V., \& Winoto, S. (2018). Gender Adjustment for Sustainable. http://ejournalfia.ub.ac.id/index.php/jiap/article/view/761

Soegijono, K.R. M. (1993). Wawancara Sebagai Salah Satu Metode Pengumpulan Data. Puslitbang Pelayanan Kesehatan; Badan Litbangkes Vol. III No. 01. https://media.neliti.com

Statistik, S. I. (2016). Potret Awal Tujuan Berkelanjutan (Sustainable Development Goals) di Indonesia. Badan Pusat Statistik, 03. http:// filantropi.or.id/pubs/uploads/files/3\%20BPS $\% 20$ Potret $\% 20 \mathrm{Aw}$ al\%20TPB\%20di\%20Indonesia.pdf 
Utami, I. H. (2017). Strategi Penguatan Kampung Glintung Go Green (3g) Sebagai Destination Branding Obyek Wisata Edukasi Di Malang. Jurnal Administrasi dan Bisnis (adbis), 11(1), 97-106. http://jadbis.polinema.ac.id/index.php/adbis/article/download/20/16

Wulan, S. (2013). Jurnal Manajemen dan Bisnis Fakultas Ekonomi Program Studi Manajemen. Universitas Bandar Lampung Vol. 3 No. 2.

Yuliyanti, T. (2018). Penguatan Institusi Lokal dan Menggerakkan Modal Sosial Melalui Komunitas Untuk Menciptakan Kampung Berdaya. JPAP: Jurnal Penelitian Administrasi Publik, 4(1). http://jurnal.untagsby.ac.id/index.php/jpap/issue/view/156/showToc

\section{Wawancara}

Wawancara dengan Bambang Irianto, (Malang, 10 Maret 2018)

Wawancara dengan Bambang Irianto, (Malang, 18 Maret 2018) 